\title{
Therapeutic Effects of Resveratrol and Baicalein on Hepatocellular Carcinoma Induced In Rats
}

Reda M.Fekry ${ }^{1}$, Akaber T. Keshta ${ }^{2}$, Shimaa R. Nawara ${ }^{3}$.

\section{Assistant Professor of organic chemistry, Chemistry} department, Faculty of Science, Zagazig University, Egypt. 2 Lecture of biochemistry, Chemistry department, Faculty of Science, Zagazig University, Egypt.

3 Biochemistry Division, Biochemistry department, Faculty of Science, Zagazig University, Egypt.

\section{A R T I CLE INF O}

Article history:

Received :

Accepted :

Available online :

Keywords: Baicalein, resveratrol, antioxidants, galectin-3, Hepatocellular carcinoma

\section{A B S T R A C T}

Background: Hepatocellular carcinoma (HCC), one of the most common cancers in the world, is a leading cause of cancer-related mortality. Resveratrol (RSV) and Baicalein (BE) are naturally derived polyphenolic compounds showed promising chemo-preventive effects against cancer. Aim: The present study aims to investigate the antioxidant activity of RSV and/or BE against induced HCC in rats. Methods: 48 Swiss male adult albino rats were divided into 6 groups: Group I served as a negative control injected intraperitoneally (I.P) with sterile saline; Group II were injected I.P with $(0.25 \%)$ Dimethylsulphoxide (DMSO); Group III were injected I.P with Diethylnitrosamine (DEN) (200 $\mathrm{mg} / \mathrm{kg}$.bw) once; Group IV injected by DEN then treated with BE (20 mg/kg.bw) I.P for 10 consecutive days; Group V injected by DEN then treated with RSV (2.5 $\mathrm{mg} / \mathrm{kg} . \mathrm{bw}$ ) orally for consecutive 10 days; Group VI injected by DEN then treated with BE and RSV. Plasma was collected for some biochemical studies and different antioxidant assays. Results: DEN-induced HCC that manifested by a significant drop in antioxidants levels, alterations in liver functions, and induced-inflammation. While, treatment with RSV and/or BE ameliorated liver injury by decreasing (alanine transferase (ALT), aspartate transferase (AST) activities, and Galectin-3 (Gal-3) levels. Also, they reversed the oxidative stress by the reduction of malondialdehyde (MDA) and nitric oxide (NO) levels and restoration of superoxide dismutase (SOD), glutathione-S-transferase (GST) activities, and reduced glutathione (GSH) levels. They decreased interlukin-6 (IL-6) levels. These data suggested that RSV or $\mathrm{BE}$ exhibited a significant role against $\mathrm{HCC}$, which 
might be related to their antioxidant and antiinflammatory activities. Conclusions: Although combined treatment with RSV and BE significantly exerting a potential therapeutic effects, individual administration was more effective in HCC treatment. These novel findings suggested that RSV and BE have an antagonistic effect suggesting concerted efforts are needed to identify the most optimal combinatorial strategies.

(c) 2016 Publisher All rights reserved.

\section{INTRODUCTION}

Hepatocellular carcinoma (HCC) is the most frequent form of primary liver cancer, it is one of the most common life threatening solid tumors with global annual diagnosis exceeding one million new cases and remains the $3^{\text {rd }}$ leading cause of cancer death ${ }^{(\mathbf{1})}$. Major risk factors for HCC include hepatitis viral infection, alcohol, environmental and industrial toxic chemicals, as

well as several dietary carcinogens, such as aflatoxins and nitrosamines, have been shown to be involved in its etiology $(2)$.

Diethylnitrosamine (DEN) is a strong hepatocarcinogenic dialkyl nitrosoamine present in tobacco smoke, water, cheddar cheese, fried meals, agricultural chemicals, cosmetics, and in a number of alcoholic beverages. DEN is metabolized to reactive electrophilic intermediates which interact with DNA causing mutation leading to carcinogenesis. Other mechanisms may be involved through DNA-adduct formation, mutagenicity, and inhibition of many enzymes involved in DNA repair mechanism and tumor initiation ${ }^{(3)}$. Since oxidative stress has been implicated in multistage hepatocarcinogenesis process, dietary antioxidants might be potential protective agents against HCC. Antioxidants are vital substances which possess the ability to protect the body from damage caused by free radical-induced oxidative stress ${ }^{(4)}$. Therefore, there is an increasing interest for natural antioxidants, e.g. polyphenols, present in medicinal and dietary plants, which might help prevent oxidative damage. In this regard, naturally occurring biologically active polyphenol compounds derived from natural sources are gaining increasing interest as potential cancer therapeutics ${ }^{(5)}$.

\section{Materials and Methods Animals}

48 adult Swiss male albino rats weighed (80-100g) were housed at animal house at the Faculty of Science, Zagazig University. The animals were maintained in controlled environment of temperature, humidity, light, and fed on a commercial standard diet and tap water ad libitum.

\section{Chemicals}

Diethylnitrosamine (DEN), Resveratrol (RSV), and Baicalein (BE) were purchased from Sigma-Aldrich Chemical Co., (St Louis, MO, USA), Galectin-3 (Gal-3) sandwich enzyme-linked immunosorbent assay (ELISA) Kit method from (BG Medicine, Waltham, MA).

\section{Induction of hepatocellular carcinoma (HCC)}

DEN was freshly dissolved in a sterile saline and injected intraperitoneally (I.P) at a dose (200/kg B.W.) once ${ }^{(12)}$.

\section{Experimental design}

Animals were divided into 6 groups (8 rats/each one) as following: Group I: Negative Control group: serving as a normal control was injected I.P with a sterile saline, Group II: DMSO group: rats were injected I.P with $(0.25 \%)$ for 10 days (13). Group III: HCC group: serving as a positive control was injected I.P with DEN (200 mg/kg.BW) once, Group IV: Baicalein-treated group (DEN+ Baicalein): rats were injected with baicalein $(20 \mathrm{mg} / \mathrm{kg} . \mathrm{BW})$ for 10 days ${ }^{(\mathbf{1 4})}$ 
after HCC induction, Group $\boldsymbol{V}$ : Resveratrol-treated (DEN+Resveratrol): rats were administrated (2.5 $\mathrm{mg} / \mathrm{kg}$. BW) of resveratrol orally for 10 days ${ }^{\text {(15) }}$ after HCC induction, Group (VI): Combination group $($ DEN + Baicalein + Resveratrol $)$ : Baicalein injected I.P \& Resveratrol administrated orally for 10 days after induction of HCC. At the end of the experiment, animals were weighed then anaesthetized under light di-ether and dissected. Blood samples were collected for biochemical analysis.

\section{(A) Biochemical analysis}

Malondialdehyde (MDA), nitric oxide (NO), and the antioxidants:superoxide dismutase (SOD), reduced glutathione (GSH), and Glutathione-S- Transferase (GST) were determined using Bio diagnostic kit method according to Satoh, (16) Montgomery and Dymock, (17) Nishikimi et al., (18), Beutler et al., (19), and Habig et al., (20) methods; respectively.

\section{Liver enzymes assessed in serum} samples:

ALT and AST were measured using Kinetic methods according to the Schumann and Klauke, ${ }_{(22)}^{(21)}$ and Karmen et al., ${ }^{22}$.

\section{Estimation of Galectin-3 (Gal-3):}

Gal-3 was determined by using a sandwich enzyme-linked immunosorbent assay (ELISA) Kit method according to the method of Christenson et al.,

\section{Interleukin-6 (IL-6) measurement:}

IL- 6 antigen was determined by ELISA using a commercially available kit from Promocell (Heidelberg, Germany) according to the method of Isomura et al.,

\section{Statistical analysis}

Data were evaluated by one-way analysis of variance (ANOVA) by "SPSS" 140 for Microsoft Windows, SPSS Inc. (25) and considered statistically significant at a two-sided $\mathrm{P}<0.05$.Numerical data were expressed as mean $\pm \mathrm{SD}$.

\section{Results}

\section{Effect of Resveratrol and Baicalein on} antioxidants in all studied groups:

The mean levels of MDA and NO in the negative control group were found to be $16.75+1.26(\mathrm{nmol} / \mathrm{ml})$ and $24.34+3.35$ $(\mu \mathrm{mol} / \mathrm{L})$; respectively. HCC group showed a significant increase in

MDA levels to be $42.36 \pm 1.94(\mathrm{nmol} / \mathrm{ml})$ by $886.25 \%$, and NO levels to be 60.39 $\pm 4.33(\mu \mathrm{mol} / \mathrm{L})$ by $148.13 \%, \quad(\mathrm{p}<0.001)$ compared to negative control group. While Resveratrol and/or Baicalein treatment showed a significant decrease in MDA levels to $6.61 \pm 0.06,10.52 \pm 0.15$, and $17.29 \pm 0.49 \quad(\mathrm{nmol} / \mathrm{ml})$ by $84.41 \%$, $112.25 \%$, and 632.36\%, $\quad(\mathrm{p}<0.001)$ respectively; compared to the HCC group. Also, NO levels were decreased significantly in Resveratrol, Baicalein, and combination groups to $12.06 \pm 1.32,18.15$ \pm 0.93 , and $32.10 \pm 2.21 \quad(\mu \mathrm{mol} / \mathrm{L})$ by $80.03 \%, \quad 87.75 \%$, and $46.83 \%$, respectively, $(\mathrm{p}<0.001)$ compared to $\mathrm{HCC}$ group, table (I).

SOD and GST activities and GSH concentration were decreased from $293.08 \pm 3.03(\mathrm{U} / \mathrm{ml}), \quad, \quad 267.20 \pm 21.05$, (U/L) $9.08 \pm 0.67(\mathrm{nmol} / \mathrm{ml})$ in negative control group to $99.11 \pm 5.08(\mathrm{U} / \mathrm{ml})$, , $126.39 \pm 16.19(\mathrm{U} / \mathrm{L}), 4.16 \pm 0.49(\mathrm{nmol} / \mathrm{ml})$ in HCC group by $66.18 \%, 54.15 \%$ and $52.70 \%$; respectively, $(\mathrm{p}<0.001)$. While, their activities were significantly increased by $505.21 \%, 215.71 \%$, and $305.57 \%$ in Resveratrol group, by $576.29 \%, 132.2 \%$, and $973.72 \%$ in Baicalein group, and by $3359.7 \%, 128.13 \%$, and $149.87 \%$ in combination group; respectively, $(\mathrm{p}<0.001)$ compared to HCC group, as shown in table (I).

\section{Effect of Resveratrol and Baicalein on liver functions in all studied groups:}

ALT and AST activities were found to be increased from 55.7+0.76 (U/L) and $118.5+0.34(\mathrm{U} / \mathrm{L})$ in negative control group to $79.84+0.87$ (U/L) and $176.45+12.52$ (U/L) in HCC group by $105.48 \%$ and 48.90\%; respectively, $(p<0.001)$. These high activities of liver 
enzymes were significantly reduced respectively in Resveratrol group by $67.647 \%$ and $39.683 \%$, and in Baicalein group by $60.598 \%$ and $45.39 \%$, and also in combination group by $48.581 \%$ and $36.322 \%$; respectively, $\quad(\mathrm{p}<0.001)$ compared to HCC group, as shown in table (II).

\section{Effect of Resveratrol and Baicalein on Galectin-3 concentration in all studied groups:}

Gal-3 concentration was significantly elevated from $3.76+0.08(\mathrm{ng} / \mathrm{ml})$ in negative control group to $22.15 \pm 1.74$ $(\mathrm{ng} / \mathrm{ml})$ in HCC group by $490.67 \%$, $(\mathrm{p}<0.001)$. While, Gal-3 was significantly decreased to $3.74 \pm 0.53(\mathrm{ng} / \mathrm{ml})$ by $83.12 \%$ in Resveratrol group, and 7.18 \pm 0.46 (ng/ml) by $98.54 \%$ in Baicalein group, and $9.17 \pm 0.81 \quad(\mathrm{ng} / \mathrm{ml})$ by $58.60 \%$ in combination group; respectively, $(\mathrm{p}<0.001)$ compared to HCC group, as shown in table (III).

\section{Effect of Resveratrol and Baicalein on Interleukin- 6 levels in all studied groups:}

IL-6 was found to be $3.18+0.32(\mathrm{pg} / \mathrm{ml})$ in negative control group, while in HCC group there was a high significant increase in serum IL-6 by $10.58 \pm 1.22(\mathrm{pg} / \mathrm{ml})$ by $233.07 \%$ compared to normal control group, Table (IV). Groups treated with Resveratrol and/or Baicalein showed a high significant decrease in IL-6 level by $1.96 \pm 0.21, \quad 5.18 \pm 0.41$, and $5.18 \pm 0.41$ (pg/ml) by $81.41 \%, 97.18 \%$, and $50.99 \%$; respectively as compared with $\mathrm{HCC}$ control group.

Hepatocellular carcinoma (HCC) is the most frequent primary hepatic malignancy, and it represents an important health issue due to its increasing incidence and poor survival, where in many years, natural products have considerable attention in scientific community for their therapeutic efficacy against various ailments such as cancer $^{(26)}$.

Our results showed that, DEN caused significant elevation in MDA \& NO levels, and significant reduction in the activity of SOD and GST and the concentration of GSH in HCC group, compared to negative group. While treatment with resveratrol and/or baicalein revealed a significant decrease by in MDA \& NO levels and a significant increase in SOD, GSH \& GST activities, compared to the HCC group. There were some alteration between DMSO group and negative control group in all studied parameters. DMSO was only used as solvent for natural products (RSV \& BE); also it used as an alternative treatment for cancer ${ }^{(27)}$.

DEN confers its hepato-carcinogenicity through its metabolic activation in the hepatic microsomes, resulting in the release of ethyl-carbonium ions that bind to the DNA, producing adducts and generating superoxide radicals through lipid peroxidation (LPO) of phospholipids membrane fatty acids ultimately leading to oxidative stress and carcinogenesis (28) The reduction in GSH level may be due to direct conjugation of GSH with electrophiles species since DEN is an electrophilic carcinogen, this depletion of $\mathrm{GSH}$, may be responsible for the increased LPO ${ }^{(29)}$.

Resveratrol has been reported to prevent oxidative stress and LPO processes, which might be due to its free radical scavenging effect; owing to the phenolic moiety present in its structure, these effects could be also related to its antioxidant properties in the liver (30). Baicalein functioned as an anti-lipid propagating agent against oxidative damage through termination of peroxyl radical-mediated reaction; depending on its lipophilicity and its ability to bind to membranes phospholipids, as it is able to restore nuclear Nrf2 protein expression and its

antioxidant response element (ARE) binding activity, which is a critical regulator of SOD and many of phase II genes such as GSTs Our findings were in accordance to many authors; Lee

et al., (32) showed that resveratrol treatment intensively lowered MDA level than ischemia rats. Gao et al., confirmed that baicalein showed a significant reduction in LPO along with a significant decrease in MDA levels. Also, Sharma et al., ${ }^{(34)}$ reported the potential protective role of resveratrol increasing hepatic SOD and GSH activities as well as activity of GST. Naveenkumar et al., 
reported that baicalein treatment recovered the decreased hepatic GSH, SOD, and GST levels towards normal. Both of resveratrol and baicalein have been reported to possess a significant antiinflammatory activity in various cells and tissues; since it decrease DEN-induced translocation of NF-kB to the nucleus; as a result reversed the elevated inducible NO synthase (iNOS) expression and thereby reduced the subsequent NO production (36). Our results were in agreement with Xin et al., ${ }^{(37)}$ who reported that baicalein is able to inhibit iNOS gene expression and down-regulate NO production induced by various inflammatory stimuli in vitro and in vivo in animal models.

Serum AST and ALT are reliable marker enzymes of liver and they are the first enzymes to be used in diagnostic enzymology as an indicator for the extent of liver damage. The elevation of these enzyme activities was indicative of the toxic effect of DEN on the liver tissue; due to over production of these enzymes in tumor cells, which might have caused increase in the permeability of cell membrane resulting in liberation of these enzymes into serum (38). Resveratrol treatment significantly attenuated the increased activities of these enzymes; which can be attributed to its capability to conserve the membrane integrity of cellular organelles ${ }^{(\mathbf{3 9})}$.

While baicalein is able to uphold parenchymal cell regeneration in liver, by repairing hepatic tissue damage caused by tumor induction, thus protecting membrane integrity and thereby decreasing enzymes leakage. In addition, it is suggested that baicalein showed significant antioxidant activity, which might be in turn responsible for its hepatoprotective activity ${ }^{(40)}$. Galectin-3 (Gal-3) is an intracellular and extracellular lectin which is presumed to interact with glycoproteins of the cell surface matrix, Gal-3 is over expressed in HCC tissues and is correlated with the tumor differentiation, suggesting that Gal-3 may be associated with the carcinogenesis and development of HCC. Thus, Gal-3 could be a novel serum tumor marker for HCC (41)

In the present study, we have observed an elevation in Gal-3

levels in HCC group compared to control group, Gal-3 expression levels increased in HCC tumor tissues relative to normal tissues, and might be associated with metastasis and cell growth

during the progression of HCC. Hence, Gal-3 might serve as a prognostic factor for $\mathrm{HCC}$ and have an important role in the diagnosis and treatment of this disease (42) . Both of resveratrol and

baicalein exert their anti-inflammatory potential through inhibition of NF-kB; thus attenuated the induction of Gal-3 in HCC cells expression at both the protein and mRNA levels

Interleukin (IL-6) levels were found to be elevated in the HCC group compared to negative control group. Meanwhile, its levels were significantly decreased after treatment with resveratrol and/or baicalein. It has been demonstrated that DENinduced inflammation triggers ROS production, which activates NF- $\kappa \mathrm{B}$ followed by release of pro-inflammatory cytokine (IL-6), chemokines and iNOS- all these events leads to hepatocarcinogenesis (44)

- Our results are consistent with the research results of Jelic et al., confirming the anti-inflammatory potential effect of resveratrol decreasing IL-6 levels.

\section{Conclusion:}

Resveratrol or Baicalein exert a potential chemotherapeutic activity against HCC induced in rats, while coadministration of both may enhance toxic effects; as the alternation in the pharmacokinetics of both natural compounds have very serious toxicological consequences.

\section{References:}

1. Mahfouzea M.K., Hassanb H.A., Alic H.A., El-Senosic Y.A., and Abd ELAzizd M.A.; (2013): Biomarker for metastasized cancer experimentally induced in mice., $B V M J ., 24$ (1):43-

50.

2. Uccello M., Malaguarnera G., Corriere T., Biondi A., Basile F., and 
Malaguarnera, M.; (2012): Risk of Hepatocellular Carcinoma in Workers Exposed to Chemicals. Hepatitis Monthly, 12(10 HCC):e5943.

3. Ahmed O.M., Ashour M.B., Fahim H.I., Mahmoud A.M., and Ahmed N.A.; (2014):

Preventive effect of spirulina versicolor and enteromorpha flexuosa ethanolic extracts against diethylnitrosamine/benzo(a)pyreneinduced hapatocarcinogencity in rats. JIARM., 2(6): 633-634.

4. Lobo V., Patil A., Phatak A., and Chandra N.; (2010): Free radicals, antioxidants and functional foods: Impact on human health. Pharmacogn. Rev., 4(8):118-126.

5. Pandey K.B., and Rizvi S.I.; (2009): Plant polyphenols as dietary antioxidants in human health and disease. Oxid. Med. Cell Longev., 2(5):270-278.

6. Athar M., Back J.H., Kopelovich L., Bickers D.R., and Kim A.L.; (2009): Multiple molecular targets of resveratrol: anti-carcinogenic mechanisms. Arch. Biochem. Biophys., 486:95e102.

7. Weng G., Zhang N., Zhong Q., Lei Z., Wu H., and Lai F.; (2016): Protective Effects Of Resveratrol Against Hypoxanthine-Xanthine Oxidase-Induced Toxicity In Human Erythrocytes.

Journal of functional foods, 23:144-153.

8. Zhang Z., Lv J., Lei X., Li S., Zhang Y., Meng L., Xue R., and Li Z.; (2014): Baicalein reduces the invasion of glioma cells via reducing the activity of p38 signaling pathway. PLoS One., 9(2):e90318.

9. Ye C, Li S, Yao W., Xu L., Oiu Y., Liu Y., Wu Z, Hou Y. (2016): The antiinflammatory effects of baicalin through suppression of NLRP3 inflammasome pathway in LPS-challenged piglet mononuclear phagocytes. Innate Immun., 22(3):196-204.

Liang R.R., Zhang S., Qi J.A., Wang Z.D., Li J., Liu P.J., Huang C., Le X.F., Yang J., and Li Z.F.; (2012): Preferential inhibition of hepatocellular carcinoma by the flavonoid baicalein through blocking MEK-ERK signaling. Int. J. Oncol.,
41(3):969-78.

11. Fang Q.Q., Ni R.Z., Xiao M.B., Jiang F., and Lu C.H.; (2011): Serum and tissue expressions of galectin-3 in hepatocellular carcinoma and the clinical significances. honghua Gan Zang Bing Za Zhi., 19(7):527-31.

12. Jahan M.S., Vani G., and Shyamalievic C.S.; (2011): Anticarcinogenic effect of

Solanum trolobatum in diethylnitrosamine induced and phenol barbital promoted hepatocarcinogenesis in rats. Asian J. of Biochemistry, 6(1):74-81.

13. Chiou W.F., Chen C.F., and Lin J.J.; (2000): Mechanisms of suppression of inducible nitric oxide synthase (iNOS) expression in RAW 264.7 cells by andrographolide. British Journal of Pharmacology, 129(8): 1553-1560.

14. Chiu Y.W., Lin T.H., Huang W.S., Teng C.Y., Liou Y.S., Kuo W.H., Lin W.L., Huang H.I., Tung J.N., Huang C.Y., Liu J.Y., Wang W.H., Hwang J.M., and Kuo H.C.; (2011):

Baicalein inhibits the migration and invasive properties of human hepatoma cells. Toxicol. Appl. Pharmacol. 255(3):316-26.

15. Khanduja K.L., Bhardwaj A., and Kaushik G.; (2004): Resveratrol inhibits $\mathrm{N}$-nitrosodiethylamine-induced ornithine decarboxylase and cyclooxygenase in mice. J. Nutr. Sci. Vitaminol., 50:61-65.

16. Satoh K.; (1978): Serum Lipid Peroxide in cerebro-vascular disorders determined by a new colorimetric method. Clinica. Chimica. Acta., 90: 37-43.

17. Montgomery H.C., and Dymock J.F., (1961): The determination of nitrite in water.

Analyst, 86: 414-416.

18. Nishikimi M., Appaji N., and Yogi K.; (1972): The occurrence of superoxide anion in the reaction of reduced phenazine methosulfate and molecular oxygen. Biochem. Bioph. Res. Commun 46: 849 854.

19. Beutler E., Duron O., and Kelly B., (1963): Improved method for the determination of blood glutathione. J. Lab. Clin. Med., 61: 882-890. 
20. Habig W.H., Pabst M.J. and Jakoby W.B.; (1974): glutathione Stransferases: the first enzymatic step in mercapturic acid formation. J. Biol. Chem., 249: 7130-7139.

21. Schumann G., and Klauke R.; (2003): New IFCC reference procedures for the determination of catalytic activity concentrations of five enzymes in serum: preliminary upper reference limits obtained in hospitalized subjects. Clin. Chim. Acta., 327(1-2): 69-

22. Karmen A., Wroblewski F., and La Due J.S.; (1955): Transaminase activity in human blood. J. Clin. Invest., 34(1):12631.

23. Christenson R.H., Duh S.H., Wu A.H., Smith A., Abel G., deFilippi C.R., Wang S., Adourian A., Adiletto C., and Gardiner P.; (2010): Multicenter determination of galectin-3 assay performance characteristics: anatomy of a novel assay for use in heart failure. Clin. Biochem., 43(7-8):683-90.

24. Isomura M., Ueno M., Shimada K., Kogaki H., and Ashihara Y.; (1994): Highly sensitive chemiluminescent enzyme immunoassay with gelatin- coated ferrite solid phase. Clin. Chem., 40:18301.

25. Levesque R.; (2007): SPSS Programming and Data Management: A Guide for SPSS and SAS Users, 4 Edition, SPSS Inc., Chicago Ill.

26. Subbaraj G.K., Kulanthaive L., Rajendran R., and Veerabathiran R.; (2013): Ethanolic Extract Of Carum Carvi (Eecc) Prevents N-Nitrosodiethylamine Induced Phenobarbital Promoted Hepatocarcinogenesis By Modulating Antioxidant Enzymes. Int. J. Pharm. Pharm. Sci., 5(1):195-199.

27. Hall M.D., Telma K.A., Chang KE., Lee T.D., Madigan JP., Lloyd JR., Goldust IS., Hoeschele J.D., and Gottesman M.M (2014): Dimethylsulfoxide inactivate ciplatin, carboplatin and other platinum complexes. Cancer Res., 74(140):3913-22.

28. Archer M.C.; (1989): Mechanisms of action of $N$-nitroso compounds. Cancer Surv., 8:241-50.
29. Pradeep K., Mohan C.V., Gobianand K., and Karthikeyan S.; (2007): Silymarin modulates the oxidant-antioxidant imbalance during diethylnitrosamine induced oxidative stress in rats. Eur. J. Pharmacol., 560:110-6.

30. Lee S.M., Yang H., Tartar D.M., Gao B., Luo X., Ye S.Q., Zaghouani H., Fang D.; (2011): Prevention and treatment of diabetes with resveratrol in a non-obese mouse model of type 1 diabetes. Diabetologia., 54(5):1136-46.

31. Lee I.K., Kang K.A., Zhang R., Kim B.J., Kang S.S., and Hyun J.W.; (2011): Mitochondria protection of baicalein against oxidative damage via induction of manganese superoxide dismutase. Environ. Toxicol. Pharmacol., 31(1):233-41.

32. Gao X.Y., Xue X.H., Ma Y.N., and Zhang S.Q.; (2015): Effect of baicalein on the expression of SATB1 in human breast cancer cells. Exp. Ther. Med., 9(5):16651669. Epub 2015 Mar 3.

33. Sharma P., Firdous S., and Singh R.; (2014): Neurotoxic effect of cypermethrin and protective role of resveratrol in Wistar rats. International Journal of Nutrition, Pharmacology, Neurological Diseases, 4(2):104-111.

34. Naveenkumar

C., Raghunandhakumar S., Asokkumar S., and Devaki T.; (2013): Baicalein abrogates reactive oxygen species (ROS)-mediated mitochondrial dysfunction during experimental pulmonary carcinogenesis in vivo. Basic Clin. Pharmacol. Toxicol., 112(4):270-81.

35. Bishayee A., Darvesh A.S., Politis T., and McGory R.; (2010): Resveratrol and liver disease: from bench to bedside and community. Liver Int., 30(8):1103-14.

36. Xia N., Förstermann U., and Li H.; (2014): Resveratrol and endothelial nitric oxide. Molecules, 19:16102-16121.

37. Revathi, R. and Manju, V. (2013): The effects of Umbelliferone on lipid peroxidation and antioxidant status in diethylnitrosamine induced hepatocellular carcinoma. Journal of Acute Medicine, 3: 7382.

38. Hussein M.A.; (2013): Prophylactic effect of resveratrol against ethinylestradiolinduced liver cholestasis. J. Med. Food., 16(3):246-54.

39. Hussein M.A.; (2013): Prophylactic 
effect of resveratrol against ethinylestradiolinduced liver cholestasis. J. Med. Food., 16(3):246-54.

40. Jiang S.S., Weng D.S., Wang Q.J., Pan K., Zhang Y.J., Li Y.Q., Li J.J., Zhao J.J., He J., Lv L., Pan Q.Z., and Xia J.C.; (2014): Galectin-3 is associated with a poor prognosis in primary hepatocellular carcinoma. J. Transl. Med.,12(1):273.

41. Nangia-Makker P., Nakahara S., Hogan V., and Raz A.; (2007): Galectin-3 in apoptosis, a novel therapeutic target. Journal of Bioenergetics and Biomembranes, 39(1):79-84.

42. Calvisi D.F., Pinna F., Ladu S., Pellegrino R., Muroni M.R., Simile M.M., Frau M., Tomasi M.L., De Miglio M.R., Seddaiu M.A., Daino L., Sanna V., Feo F., and Pascale R.M.; (2005): Aberrant iNOS signaling is under genetic control in rodent liver cancer and potentially prognostic for the human disease. Carcinogenesis, 29(8):163947.

43. 43. Tsukamoto M., Sango K., Niimi N., Yanagisawa H., Watabe $K$., and Utsunomiya K.; (2015): Upregulation of galectin-3 in immortalized Schwann cells IFRS1 under diabetic conditions. Neurosci. Res., 92:80-5.

44. Zagotta I., Dimova E.Y., Debatin K.M., Wabitsch M., Kietzmann T., Fischer- Posovszky P.; (2015): Obesity and inflammation: reduced cytokine expression due to resveratrol in a human in vitro model of inflamed adipose tissue. Front Pharmacol., 6:79.

45. Jelic D., Loweknedza A.D., Brantner A.H., Blazekovic B., Bian B., Yang J., Brajsa K., and Knezevic S.V.; (2016): Baicalin and Baicalein inhibit Src Zyrosine Kinase and production of IL-6. Journal of chemistry,2016:6. 
Table (I): Changes in levels of antioxidants in all studied groups:

\begin{tabular}{|c|c|c|c|c|c|c|c|c|c|c|c|c|}
\hline \multirow[b]{2}{*}{ Variable } & \multicolumn{2}{|c|}{$\begin{array}{c}\text { Negative control } \\
\text { group }\end{array}$} & \multicolumn{2}{|c|}{ DMSO Control } & \multicolumn{2}{|c|}{ HCC Control Group } & \multicolumn{2}{|c|}{$\begin{array}{c}\text { Resveratrol Group } \\
\text { (DEN+ RSV) }\end{array}$} & \multicolumn{2}{|c|}{$\begin{array}{c}\text { Baicalein Group } \\
\text { (DEN + BE) }\end{array}$} & \multicolumn{2}{|c|}{$\begin{array}{c}\text { Combination Group } \\
\text { (DEN+RSV+BE) }\end{array}$} \\
\hline & Mean \pm SD. & s。 & Mean \pm SD. & o & Mean \pm SD. & s & Mean \pm SD. & s & Mean \pm SD. & o & Mean \pm SD. & o 芯 \\
\hline $\begin{array}{c}\text { MDA } \\
(\mathbf{n m o l} / \mathbf{m l})\end{array}$ & $16.75+1.26$ & ------ & $14.73+1.94$ & -12.09 & $42.36+1.94 \mathrm{a}$ & +886.25 & $6.61+0.06 b$ & -84.41 & $10.52 \pm 0.15 b$ & -112.25 & $17.29 \pm 0.49 b$ & +632.63 \\
\hline $\begin{array}{c}\text { NO } \\
(\mathrm{nmol} / \mathrm{ml})\end{array}$ & $24.34+3.35$ & ------ & $19.75+1.17 \mathrm{a}$ & -18.85 & $60.39+4.33 a$ & +148.13 & $12.06+1.32 b$ & -80.03 & $18.15 \pm 0.93 b$ & -87.751 & $32.10 \pm 2.21 \mathrm{~b}$ & -46.83 \\
\hline $\begin{array}{l}\text { SOD } \\
(\mathrm{U} / \mathrm{L})\end{array}$ & $293.08+3.03$ & ------ & $251.38+2.55 \mathrm{a}$ & -14.23 & $99.11+5.08 \mathrm{a}$ & -66.18 & $599.84+45.39 b$ & +505.21 & $461.48 \pm 30.36 \mathrm{~b}$ & -576.29 & $315.18 \pm 1.21 \mathrm{~b}$ & +3359.7 \\
\hline $\begin{array}{c}\text { GSH } \\
(\mathbf{n m o l} / \mathbf{m l})\end{array}$ & $9.08+0.67$ & ------- & $8.14+0.05 \mathrm{a}$ & -10.29 & $4.16+0.49 a$ & -54.15 & $13.14+1.12 b$ & +215.71 & $17.43 \pm 1.13 \mathrm{~b}$ & -132.2 & $9.49 \pm 0.04 b$ & +128.13 \\
\hline $\begin{array}{c}\text { GST } \\
(\mathrm{nmol} / \mathrm{ml})\end{array}$ & $267.2+21.05$ & ------- & $324.28+1.81 \mathrm{a}$ & +21.36 & $126.39+16.19 a$ & -52.70 & $512.59+7.97 b$ & +305.57 & $460.47 \pm 41.51 b$ & -973.72 & $315.78 \pm 9.36 b$ & +149.87 \\
\hline
\end{tabular}

Significant difference from control value at $\mathrm{P}<0.001$,

(a) Compared with negative control

(b) Compared with HCC group

Table (II): Changes in liver enzymes activities in all studied groups:

\begin{tabular}{|c|c|c|c|c|c|c|c|c|c|c|c|c|}
\hline \multirow[b]{2}{*}{ Variable } & \multicolumn{2}{|c|}{$\begin{array}{c}\text { Negative control } \\
\text { group }\end{array}$} & \multicolumn{2}{|c|}{ DMSO Control } & \multicolumn{2}{|c|}{ HCC Control Group } & \multicolumn{2}{|c|}{$\begin{array}{c}\text { Resveratrol Group } \\
\text { (DEN+ RSV) }\end{array}$} & \multicolumn{2}{|c|}{$\begin{array}{c}\text { Baicalein Group } \\
\text { (DEN+ BE) }\end{array}$} & \multicolumn{2}{|c|}{$\begin{array}{c}\text { Combination Group } \\
(\mathrm{DEN}+\mathrm{RSV}+\mathrm{BE})\end{array}$} \\
\hline & Mean \pm SD. & $0 \frac{8}{0}$ & Mean \pm SD. & $\therefore$ & Mean \pm SD. & $\therefore$ & Mean \pm SD. & $\therefore$ & Mean \pm SD. & 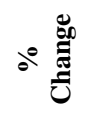 & Mean \pm SD. & 。 \\
\hline $\begin{array}{l}\text { ALT } \\
(\mathbf{U} / \mathbf{L})\end{array}$ & $55.7+0.76$ & - & $79.84+0.87 \mathrm{a}$ & +43.33 & $114.45+1.93 \mathrm{a}$ & $\begin{array}{c}+105.4 \\
8\end{array}$ & $\begin{array}{c}37.06 \pm .077 \\
\mathrm{~b}\end{array}$ & -67.647 & $\begin{array}{c}41.63 \pm 0.48 \\
\text { b }\end{array}$ & $\begin{array}{c}- \\
60.598\end{array}$ & $58.90 \pm 1.13 b$ & -48.581 \\
\hline $\begin{array}{c}\text { AST } \\
(\mathbf{U} / \mathbf{L})\end{array}$ & $118.5+0.34$ & $\begin{array}{l}-- \\
-\end{array}$ & $95.06+0.51 \mathrm{a}$ & -19.78 & $\begin{array}{c}176.45+12.52 \\
\text { a }\end{array}$ & +48.90 & $\begin{array}{c}106.43 \pm 1.1 \\
8 \mathrm{~b}\end{array}$ & -39.683 & $\begin{array}{c}71.10 \pm 4.98 \\
\text { b }\end{array}$ & 45.39 & $112.36 \pm 0.52 b$ & -36.322 \\
\hline
\end{tabular}

Significant difference from control value at $\mathrm{P}<0.001$

(a) Compared with negative control

(b) Compared with HCC group

Table (III): Changes in Galectin-3 concentration in all studied groups:

\begin{tabular}{|c|c|c|c|c|c|c|c|c|c|c|c|c|}
\hline \multirow[b]{2}{*}{ Variable } & \multicolumn{2}{|c|}{$\begin{array}{c}\text { Negative control } \\
\text { group }\end{array}$} & \multicolumn{2}{|c|}{ DMSO Control } & \multicolumn{2}{|c|}{ HCC Control Group } & \multicolumn{2}{|c|}{$\begin{array}{l}\text { Resveratrol Group } \\
\text { (DEN+ RSV) }\end{array}$} & \multicolumn{2}{|c|}{$\begin{array}{c}\text { Baicalein Group } \\
\text { (DEN+ BE) }\end{array}$} & \multicolumn{2}{|c|}{$\begin{array}{c}\text { Combination Group } \\
\text { (DEN+RSV+BE) }\end{array}$} \\
\hline & Mean \pm SD. & $\therefore$ 造 & Mean \pm SD. & of & Mean \pm SD. & o & Mean \pm SD. & o & Mean \pm SD. & o & Mean \pm SD. & o \\
\hline $\begin{array}{c}\text { Gal-3 } \\
(\mathbf{n g} / \mathrm{ml})\end{array}$ & $3.76+0.08$ & -- & $4.00+0.33 \mathrm{a}$ & +6.56 & $22.15 \pm 1.74 \mathrm{a}$ & 490.67 & $3.74 \pm 0.53 \mathrm{~b}$ & -83.12 & $7.18 \pm 0.46 \mathrm{~b}$ & -98.54 & $9.17 \pm 0.81 \mathrm{~b}$ & -58.60 \\
\hline
\end{tabular}

Significant difference from control value at $\mathrm{P}<0.001$

(a) Compared with negative control

(b) Compared with HCC group 
Table (IV): Changes in levels of IL-6 in all studied groups:

\begin{tabular}{|c|c|c|c|c|c|c|c|c|c|c|c|c|}
\hline \multirow[b]{2}{*}{$\begin{array}{c}\text { Variab } \\
\text { le }\end{array}$} & \multicolumn{2}{|c|}{$\begin{array}{c}\text { Negative control } \\
\text { group }\end{array}$} & \multicolumn{2}{|c|}{ DMSO Control } & \multicolumn{2}{|c|}{ HCC Control Group } & \multicolumn{2}{|c|}{$\begin{array}{c}\text { Resveratrol Group } \\
\text { (DEN+ RSV) }\end{array}$} & \multicolumn{2}{|c|}{$\begin{array}{c}\text { Baicalein Group } \\
\text { (DEN+ BE) }\end{array}$} & \multicolumn{2}{|c|}{$\begin{array}{c}\text { Combination Group } \\
(\mathrm{DEN}+\mathrm{RSV}+\mathrm{BE})\end{array}$} \\
\hline & Mean \pm SD. & o & $\begin{array}{l}\text { Mean } \\
\pm \text { SD. }\end{array}$ & 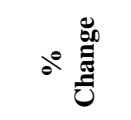 & Mean \pm SD. & $\therefore$ 递 & $\begin{array}{l}\text { Mean } \\
\pm \text { SD. }\end{array}$ & \& & Mean \pm SD. & 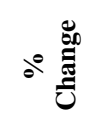 & Mean \pm SD. & o \\
\hline $\begin{array}{c}\text { IL-6 } \\
(\mathrm{pg} / \mathrm{ml} \\
\text { ) }\end{array}$ & $3.18+0.32$ & --- & $3.49+0.67 \mathrm{a}$ & $1.97+0.21$ & $10.57 \pm 1.22 \mathrm{a}$ & 233.07 & $1.96 \pm .21 \mathrm{~b}$ & -81.41 & $6.58 \pm 0.62 b$ & -97.18 & $5.18 \pm 0.41 b$ & -50.99 \\
\hline
\end{tabular}

Significant difference from control value at $\mathrm{P}<0.001$, (a) Compared with negative control , (b) Compared with HCC group 